\title{
Can silicate and turbulence regulate the vertical flux of biogenic matter? A mesocosm study
}

\author{
Camilla Svensen $^{1, *}$, Jorun K. Egge ${ }^{2}$, Jan Erik Stiansen ${ }^{3}$ \\ ${ }^{1}$ Norwegian College of Fishery Science, University of Tromsø, Tromsø 9037, Norway \\ ${ }^{2}$ Department of Fisheries and Marine Biology, University of Bergen, HIB, Bergen 5020, Norway \\ ${ }^{3}$ Institute for Marine Research, PO Box 1870, Nordnes 5817, Norway
}

\begin{abstract}
The effects of silicate and turbulence on the vertical flux of biogenic matter were studied in mesocosms. The experiment consisted of eight $27 \mathrm{~m}^{3}$ enclosures all fertilised with nitrate and phosphate (NP), while 4 of the enclosures were supplied with silicate as well (NPS). A 2-layer density gradient was created, and turbulence was generated at 2 intensity levels in the upper layer of the enclosures by a vertically moving grid. We tested the hypotheses that: (1) dissolved silicate (DSi) has a strong regulating effect on biogenic sedimentation by favouring the growth of diatoms instead of flagellates; (2) there is a positive linear relationship between DSi consumption and carbon export; and (3) elevated levels of turbulence would further increase the loss rates of diatoms through aggregate formation. Addition of DSi caused higher primary production and a shift from a flagellate to diatom-dominated phytoplankton community. However, contrary to expectations, sedimentation of chl a was lower $\left(<15 \mathrm{mg} \mathrm{m}^{-2} \mathrm{~d}^{-1}\right)$ where diatoms dominated than where flagellates prevailed $(\leq 80 \mathrm{mg}$ $\mathrm{m}^{-2} \mathrm{~d}^{-1}$ ). The hypothesised linear relationship between addition of DSi and vertical export was thus not found in this experiment. The 2 levels of turbulence caused no statistically significant differences in the suspended concentrations or sedimentation rates of phytoplankton groups. In conclusion, DSi triggered a diatom bloom with stable sedimentation rates in the NPS replicates, while comparatively higher loss rates were found in the flagellate-dominated NP enclosures. Turbulence had little effect on the phytoplankton community and sedimentation of biogenic matter.
\end{abstract}

KEY WORDS: Vertical flux $\cdot$ Silicate $\cdot$ Turbulence $\cdot$ Diatoms $\cdot$ Phaeocystis pouchetii $\cdot$ Mesocosm Resale or republication not permitted without written consent of the publisher

\section{INTRODUCTION}

Energy and carbon flow through the food web may take different pathways. The traditional, 'classical' food chain has been described as a 'phytoplanktonzooplankton-fish' type, where large cells (e.g. diatoms) fuel fish production. This kind of food chain based on diatoms is considered economically more attractive than for instance one based on flagellates or groups that are likely to remain ungrazed by large zooplankton (Officer \& Ryther 1980, Ryther \& Officer 1981). Therefore, much emphasis has been placed on understanding what factors control diatom growth under close to in situ conditions, and several of these studies have been conducted in large enclosures. From a large

*E-mail: camillas@nfh.uit.no number of mesocosm experiments at different seasons and nutrient concentrations and ratios, the conclusion was drawn that with $\mathrm{N}$ and $\mathrm{P}$ present diatoms were most likely to dominate phytoplankton growth at silicate concentrations $>2 \mu \mathrm{M}$ (Egge \& Aksnes 1992). The presence of diatoms could thus be easily regulated by controlling the silicate supply to the system. In areas where Si:N and Si:P ratios are declining because of human impact (i.e. eutrophication), addition of silicate has even been suggested as a remedy for undesirable effects (Officer \& Ryther 1980, Sommer 1996). Decreased Si:N ratio has led to competitive advantage of the non-siliceous taxa over diatoms, implying less efficient transfer of energy and matter from primary producers to fish (Officer \& Ryther 1980).

However, relatively little is known about how dissolved silicate (DSi) concentrations will affect the ver- 
tical flux of biogenic matter, although this could provide important information about pelagic food web efficiency. An efficient food chain based on diatoms should give rise to high vertical export of carbon, either through aggregates or faecal pellets (Ryther \& Officer 1981, Smetacek et al. 1984, Peinert et al. 1989, Passow et al. 1994). From a mesocosm experiment in which DSi was added in moderate concentrations corresponding to $3 \mu \mathrm{M}$, Wassmann et al. (1996) postulated that 'presence of dissolved silicate appears to decrease the nutrient turn-over time in the euphotic zone by increasing vertical export'. Furthermore the authors suggested that there may be a curve-linear relationship between added (or consumed) DSi and carbon export (when N and $\mathrm{P}$ are available at non-limiting concentrations), until phytoplankton growth is limited by other factors such as light. It remains to be seen if this suggestion is valid over the entire range of DSi concentrations.

Turbulence intensity is another factor that is believed to have an impact on the structure of the pelagic food web, for instance by promoting growth of larger cells such as diatoms (Nielsen \& Kiørboe 1991, Kiørboe 1993) and inhibiting dinoflagellates (Margalef 1978, Margalef et al. 1979). Turbulence, cell size and abundance determine the collision frequency of suspended phytoplankton cells, and some of these will stick together and gradually build up larger aggregates with enhanced settling velocities (Kiørboe 1993, Ruiz 1996). While this may increase the vertical flux of biogenic matter, turbulence may also decrease sedimentation by increased grazing pressure (Petersen et al. 1998) and, if strong enough, also disrupt aggregates (Alldredge et al. 1990). Although extensive theoretical work on the effect of turbulence on sedimentation is available (see for instance Kiørboe 1993 and references therein), less effort

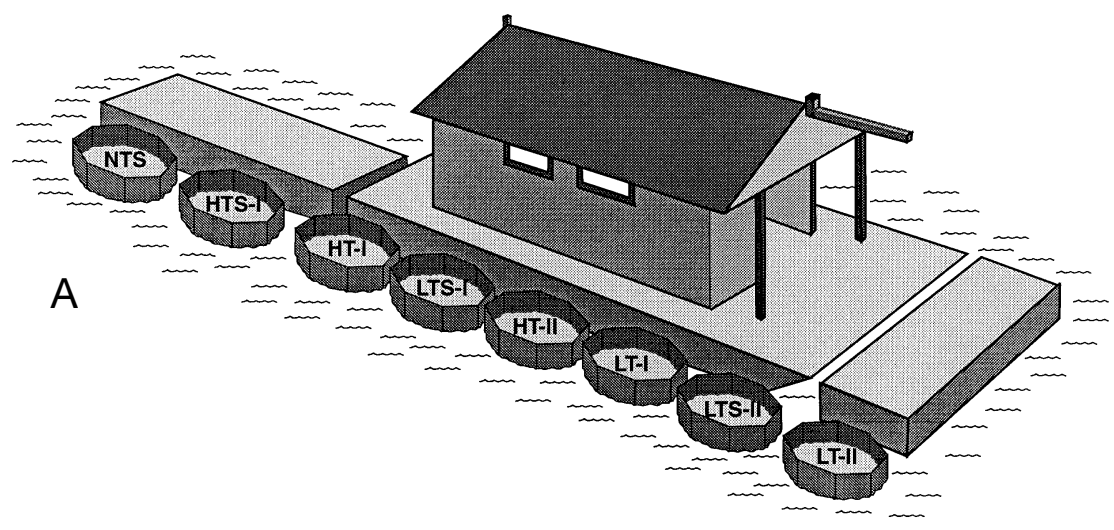

Fig. 1. (A) Arrangement of the enclosures on the raft. (B) Close-up sketch of an enclosure, showing turbulence-generating grids, sediment traps and positions for suspended sampling. The airlift penetrated $4 \mathrm{~m}$ down in the centre of the enclosure and provided circulation in the upper $4 \mathrm{~m}$ of the enclosure at a rate of $40 \mathrm{l} \mathrm{min}^{-1}$ has been given to testing these theoretical assumptions at an ecosystem and community level under more natural, but controlled conditions.

In order to investigate the relationship between added DSi and vertical carbon export under controlled conditions, we fertilised large mesocosm enclosures with nitrogen, phosphorus and silicate. Furthermore we attempted to identify the possible impact of 2 different levels of turbulence (within the range of turbulence intensities reported in coastal areas) on the vertical flux of carbon. We wanted to test the following hypotheses: (1) addition of DSi will favour the growth of diatoms and thereby lead to increased sedimentation of biogenic matter; (2) there is a positive linear relationship between DSi consumption and carbon export (Wassmann et al. 1996); (3) higher turbulence intensity will cause higher phytoplankton sedimentation than lower turbulence intensities.

\section{MATERIALS AND METHODS}

Experimental design and enclosure treatments. The experiment was carried out between 5 and 29 April 1997 at the Marine Biological Field Station in Raunefjorden, outside Bergen, Norway. Eight $27 \mathrm{~m}^{3}$ polyethylene enclosures (depth $9.3 \mathrm{~m}$, diameter $2 \mathrm{~m}$ ) with $90 \%$ light penetration were moored to floating frames and arranged on the south side of a raft (Fig. 1A). They were open to the atmosphere and had a conical end 
(Fig. 1B). An airlift-system provided homogeneity in the upper layer by circulating water from $4 \mathrm{~m}$ depth to the surface (Fig. 1B) at a pumping rate of $401 \mathrm{~min}^{-1}$ (Jacobsen et al. 1995). As an attempt to minimise the disturbance from wind-induced waves on the enclosures, an oil boom was arranged in a circle around the raft. The boom penetrated ca $1 \mathrm{~m}$ down into the sea and was anchored to the bottom.

The enclosures were filled simultaneously by pumping unfiltered seawater from $5 \mathrm{~m}$ into a large tank with separate outlets. In order to increase the salinity of the bottom layer in the enclosures by 1.5, seawater saturated with $\mathrm{NaCl}$ was supplied to the large tank when the bottom $13 \mathrm{~m}^{3}$ was filled. An open valve was mounted to each enclosure, allowing approximately $6 \%$ daily exchange of surface water. Renewal water was pumped from $5 \mathrm{~m}$ depth into a large tank and then fed through tubes to each of the enclosures by outlets at 4 and $7 \mathrm{~m}$. The flow to the upper layer consisted of natural seawater, while the flow to the bottom layer was filtered $(10 \mu \mathrm{m})$ seawater with an increased salinity of 1.5 (S. Nerheim et al. unpubl. data). To compensate for loss of nutrients due to renewal of water, $10 \%$ of the initial addition was supplied daily to the upper layer. Flow-through enclosures were chosen because they allow the introduction of new phytoplankton species and prevents an increase in $\mathrm{pH}$ caused by higher primary production (for further details see Egge 1993).

An overview of treatments given to each enclosure is summarised in Table 1. Nitrogen $\left(\mathrm{NaNO}_{3}\right)$ and phosphate $\left(\mathrm{KH}_{2} \mathrm{PO}_{4}\right)$ were added to the upper layer of all enclosures on 5 April, while silicate $\left(\mathrm{Na}_{2} \mathrm{SiO}_{3} \cdot 5 \mathrm{H}_{2} \mathrm{O}\right)$ was added to only 4 of the enclosures. Nutrient additions corresponded to $15 \mu \mathrm{M}$ nitrate, $1 \mu \mathrm{M}$ phosphate and $10 \mu \mathrm{M}$ silicate. Turbulence was generated in all enclosures, but with 2 different intensity levels (for simplicity termed 'high' or 'low'). All treatments were given 2 replicate enclosures, indicated by the number I or II throughout this paper.

Turbulence was generated in the upper layer by a vertically moving grid, driven by 3 pneumatic cylin-

Table 1. Treatment terminology. Nitrate and phosphate (NP) and nitrate, phosphate and silicate (NPS) enclosures and nutrient doses. Enclosures treated with low/high turbulence; replicate treatments designated by I or II throughout text. Note: during HTS-II the turbulence generation system broke down so this treatment was renamed NTS (no turbulence, plus silicate)

\begin{tabular}{|lcc|}
\hline & $\mathrm{NP}:$ & $\mathrm{NPS}:$ \\
& $15 \mu \mathrm{MN}+1 \mu \mathrm{MP}$ & $15 \mu \mathrm{MN}+1 \mu \mathrm{MP}+10 \mu \mathrm{MSi}$ \\
\hline Low turbulence & LT & LTS \\
High turbulence & HT & HTS \\
\hline
\end{tabular}

ders (Fig. 1b). The grid had a diameter of $1.5 \mathrm{~m}$ and was made of plexiglass that allowed $95 \%$ penetration of PAR. The grid had a bar width of $5 \mathrm{~cm}$, a mesh size of $10 \mathrm{~cm}$ and a stroke-length of $40 \mathrm{~cm}$, centred at a depth of $1.0 \mathrm{~m}$. A part of the grid could be removed to make sampling from the enclosures possible. The 2 turbulence regimes were generated by differing the oscillation periods. A discontinuous oscillation cycle was electronically set to start a half-period each $7 \mathrm{~s}$ in the high turbulence case (HT) and each $28 \mathrm{sec}$ in the low turbulence case (LT). Each half-period consisted of an interval of grid motion followed by an interval of rest. In the high turbulence case the periods of motion and rest were 5 and $2 \mathrm{~s}$, respectively, whereas in the low turbulence case the same periods were 10 and 18 s. On 13 April the turbulence generation system broke down in one of the high turbulence enclosures (HTS-II), and was switched off for the rest of the experiment (leaving the grid in the lowest position at $1.2 \mathrm{~m}$ ). This enclosure will therefore be referred to as a noturbulence enclosure (NTS), although 'background' turbulence was still present in the enclosures generated by the airlift and external forcing. (S. Nerheim et al. unpubl. data).

Sampling procedures and turbulence measurements. Sampling from the mesocosms at 2 and $6 \mathrm{~m}$ depth was performed every second day at 09:00 h. Subsamples were collected for the determination of suspended chlorophyll a (chl a), particulate organic carbon (POC) and nitrogen (PON), and nutrients. Samples for phytoplankton species composition were taken from $2 \mathrm{~m}$ only and preserved with a glutaraldehydeLugol solution ( $2 \%$ final concentration, Rousseau et al. 1990).

Vertical flux was measured with sediment traps consisting of 2 parallel plexiglass cylinders (aspect ratio $6.25)$, positioned at $8 \mathrm{~m}$ in the centre of the enclosures (Fig. 1b). The traps were emptied every second day, and no poison was used during the deployment period. The content of each cylinder (1.8 l) was gently mixed and diluted to 21 before subsampling. Triplicate subsamples of 25 to $150 \mathrm{ml}$ were taken for determination of chl $a$, POC and PON. As far as possible, swimmers were removed from the filters with forceps to prevent contamination (Lee et al. 1988). Subsamples of $100 \mathrm{ml}$ were taken from the sediment traps every second sampling day for 1 replicate only (i.e. enclosures LT-I, LTS-I, HT-I and HTS-I) and preserved with Lugol-mix for analysis of phytoplankton composition and faecal pellets.

Turbulence intensities were calculated in terms of energy dissipation rates $(\varepsilon)$, calculated from velocity time series, using the method of linear regression described in Stiansen \& Sundby (in press). The velocity time series were measured using a focusing acoustic 
current meter (ADV lab probe, from NORTEK) with a sampling frequency of $25 \mathrm{~Hz}$, and a resolution of $0.1 \mathrm{~mm} \mathrm{~s}^{-1}$. The ADV is fully described in Kraus et al. (1994). A total of 103 time series were taken during the experiment. The energy dissipation rates for each of the 3 velocity components were calculated. Bad components were removed, and a logarithmic mean for each time series was calculated from the remaining components (the logarithmic mean was preferred because it is more robust towards a single high value than the sample mean).

Surface irradiance (PAR) was registered continuously, and data stored as average values every $10 \mathrm{~min}$ in a Li-Cor Li-1000 data logger. Salinity (S) and temperature $\left({ }^{\circ} \mathrm{C}\right)$ were measured each day with a Seacat profiler (Sea Bird Electronics, Bellevue, WA, USA).

Analysis and calculations. Chl a samples were filtered onto Sartorius filters $(0.45 \mu \mathrm{m})$, extracted in $10 \mathrm{ml}$ $90 \%$ acetone for 8 to $12 \mathrm{~h}$ (Parsons et al. 1984) and analysed on a Turner Design Fluorometer (Model 10AU) without acidification (Welschmeyer 1994). The POC samples were filtered onto pre-combusted Whatman GF/F glass-fiber filters and analysed on a Leeman Lab CEC 440 elemental analyser after removal of carbonate with fumes of concentrated $\mathrm{HCl}$. Water samples of $100 \mathrm{ml}$ for measurements of primary production were incubated every second day at 2 and $6 \mathrm{~m}$ between 10:00 and 14:00 $\mathrm{h}$ in the center of the enclosures. Primary production was measured using the ${ }^{14} \mathrm{C}$ method according to Steemann Nielsen (1952) and Gargas (1975). The samples were filtered onto Sartorius membrane filters $(0.45 \mu \mathrm{m})$, frozen, and later counted in a Packard Tricarb Liquid Scintillation Analyser (Model $1900 \mathrm{CA}$ ) after fuming with $\mathrm{HCl}$. Daily production rates was calculated according to light intensity during the incubation time. Nutrients were measured from freshly collected samples using a Skalar autoanalyser. The silicate values obtained by this method were adjusted by subtracting $1.3 \mu \mathrm{M}$ to correct for biased blank values. Additional measurements and $\mathrm{Si}$ uptake kinetic experiments demonstrated that this correction was reasonable (S. Kristiansen unpubl. results). Values $<0.1 \mu \mathrm{M}$ (detection limit) were set to zero.

Integration of chl $a$, suspended biomass and nutrients were made on the assumption that samples taken from $2 \mathrm{~m}$ were representative for the mixed upper layer of the enclosures (about $4 \mathrm{~m}$ ), while the samples taken at $6 \mathrm{~m}$ were representative for the 4 to $8 \mathrm{~m}$ depth interval. The consumption of nutrients (N, P and $\mathrm{Si}$ ) in each enclosure was calculated as:

$$
N_{\text {consumed }}=N_{\text {start }}-N_{\text {end }}+N_{\text {add }}+N_{\text {in }}-N_{\text {out }}
$$

where $N$ represents the type of nutrient, $N_{\text {start }}$ the start concentration, $N_{\text {end }}$ the end concentration. $N_{\text {add }}$ is the concentration added to the enclosures, $N_{\text {in }}$ the concentration supplied with the intake water, and $N_{\text {out }}$ the concentration leaving the enclosures through the open valve. The $N_{\text {out }}$ estimates are based on measurements of the nutrient concentration in the mixed layer of the enclosures and the flow out of each enclosure, while $N_{\text {in }}$ estimates are correspondingly calculated from the flow rate and the nutrient concentrations of the intake water to the upper and lower layer.

Suspended phytoplankton was enumerated and identified using the sedimentation method of Utermöhl (1931). Phytoplankton from the sediment traps was counted using a combination of methods according to Sournia (1978) as described by Ratkova et al. (1999). Biovolumes of individual cells were calculated from linear dimensions of measured cells applied to appropriate stereometric formulae (Smayda 1978). The carbon content of the algae (PPC) was calculated based on average volume of the different species and according to Strathmann (1967). A volumetric carbon conversion factor of $69.4 \mu \mathrm{g} \mathrm{C} \mathrm{mm}{ }^{-3}$ (Riebesell et al. 1995) was applied to estimate faecal pellet carbon (FPC). The carbon content of microzooplankton (mainly ciliates) was

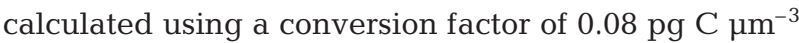
according to Garrison \& Buck (1989).

The effect of nutrients and turbulence on the suspended phytoplankton community (chl a concentrations, POC, primary production and phytoplankton groups) and on the vertical flux of biogenic matter (chl a and POC) was tested with ANOVA repeated measures (Type III model). Each enclosure was defined as subject, with time as the repeated effect. Time was also included in the model to correct for time-dependency of data. When necessary, data were logarithmically transformed to obtain normality in the distribution.

\section{RESULTS}

\section{Physical environment and development of turbulence regimes}

Mean daily irradiance was $25 \mathrm{~mol} \mathrm{~m}^{-2} \mathrm{~d}^{-1}$ (range 4 to $40 \mathrm{~mol} \mathrm{~m}^{-2} \mathrm{~d}^{-1}$ ). There was a slight increase in daily irradiance during the experiment (Fig. 2). The temperature increased from 5 to $7.5^{\circ} \mathrm{C}$ during April in the sea and in the enclosures. All enclosures had a mixed upper layer and a more stagnant lower layer, separated by a pycnocline. The depth of the upper layer was controlled by the turbulence input and the salinity difference across the pycnocline. In the low turbulence enclosures and the NTS enclosure, the depth of the upper layer was constant at 4 to $4.5 \mathrm{~m}$ throughout the experiment. In the high turbulence enclosures it increased from $4-4.5$ to 5.5-6.5 m after 9 April, after 


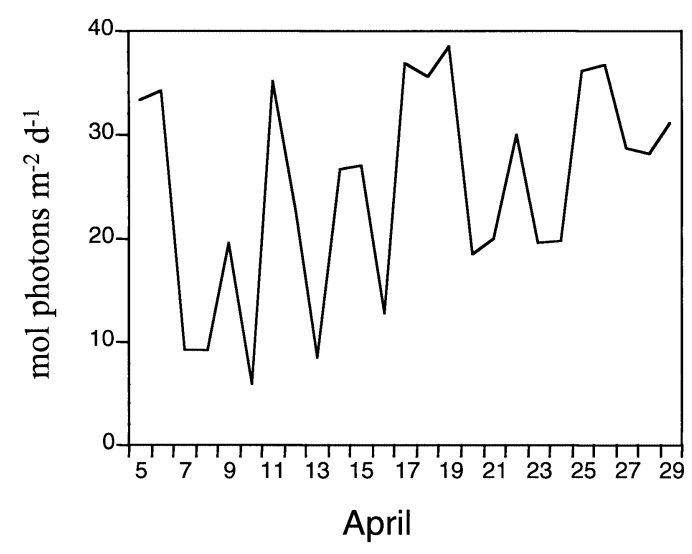

Fig. 2. Development of surface irradiance (photosynthetically active radiation, PAR) during the experimental period

which it stayed stable (Fig. 3A). The pycnocline was always well above the sediment traps positioned at $8 \mathrm{~m}$ depth.

The average energy dissipation rates for HT, LT and NT in the upper layer were $1.9 \times 10^{-7}, 5.5 \times 10^{-8}$ and $2.8 \times 10^{-8} \mathrm{~W} \mathrm{~kg}^{-1}$, respectively, and were always weaker in the lower layer $\left(7.6 \times 10^{-8}, 2.0 \times 10^{-8}\right.$ and $5.3 \times$ $10^{-9} \mathrm{~W} \mathrm{~kg}^{-1}$, respectively) (Table 2 ). The wind velocity needed to create such turbulence at $5 \mathrm{~m}$ depth (MacKenzie \& Leggett 1993) was $\sim 3$ to $6 \mathrm{~m} \mathrm{~s}^{-1}$ in the upper and 2 to $4 \mathrm{~m} \mathrm{~s}^{-1}$ in the lower layer (Table 2). The average energy dissipation rates as a function of depth for the 3 turbulence regimes are shown in Fig. 3B. The decay of turbulence with distance from the energy source was clear in the high turbulence regime, but less so in the low and no turbulence regime. This was due to a relatively high 'background' turbulence caused by the airlift circulation and from wave-enclosure interaction.

\section{Nutrients}

Initial concentrations of nitrate, phosphate and silicate were low (1.23 to $1.78 \mu \mathrm{M}, 0.08$ to $0.5 \mu \mathrm{M}$ and $<0.1$ to $0.3 \mu \mathrm{M}$, respectively), with no significant difference

Table 2. Average energy dissipation rates $\left(\mathrm{W} \mathrm{kg}^{-1}\right)$ in upper and lower layers of the high turbulence (HT), low turbulence (LT) and no turbulence (NT) enclosures. The wind speed $\left(\mathrm{m} \mathrm{s}^{-1}\right)$ necessary to create the corresponding turbulence at

$5 \mathrm{~m}$ depth is calculated from MacKenzie \& Leggett (1993)

\begin{tabular}{|lcccc|}
\hline \multicolumn{2}{|c|}{$\begin{array}{c}\text { Energy dissipation }\left(\mathrm{W} \mathrm{kg}^{-1}\right) \\
\text { Upper layer }\end{array}$} & \multicolumn{2}{c|}{ Lower layer } & Wind speed $\left(\mathrm{m} \mathrm{s}^{-1}\right)$ \\
& & & \\
& & & \\
Upper layer & Lower layer \\
LT & $1.9 \times 10^{-7}$ & $7.6 \times 10^{-8}$ & 5.5 & 4.0 \\
NT & $5.5 \times 10^{-8}$ & $2.0 \times 10^{-8}$ & 3.6 & 2.6 \\
& $2.8 \times 10^{-8}$ & $5.3 \times 10^{-9}$ & 2.9 & 1.7 \\
\hline
\end{tabular}
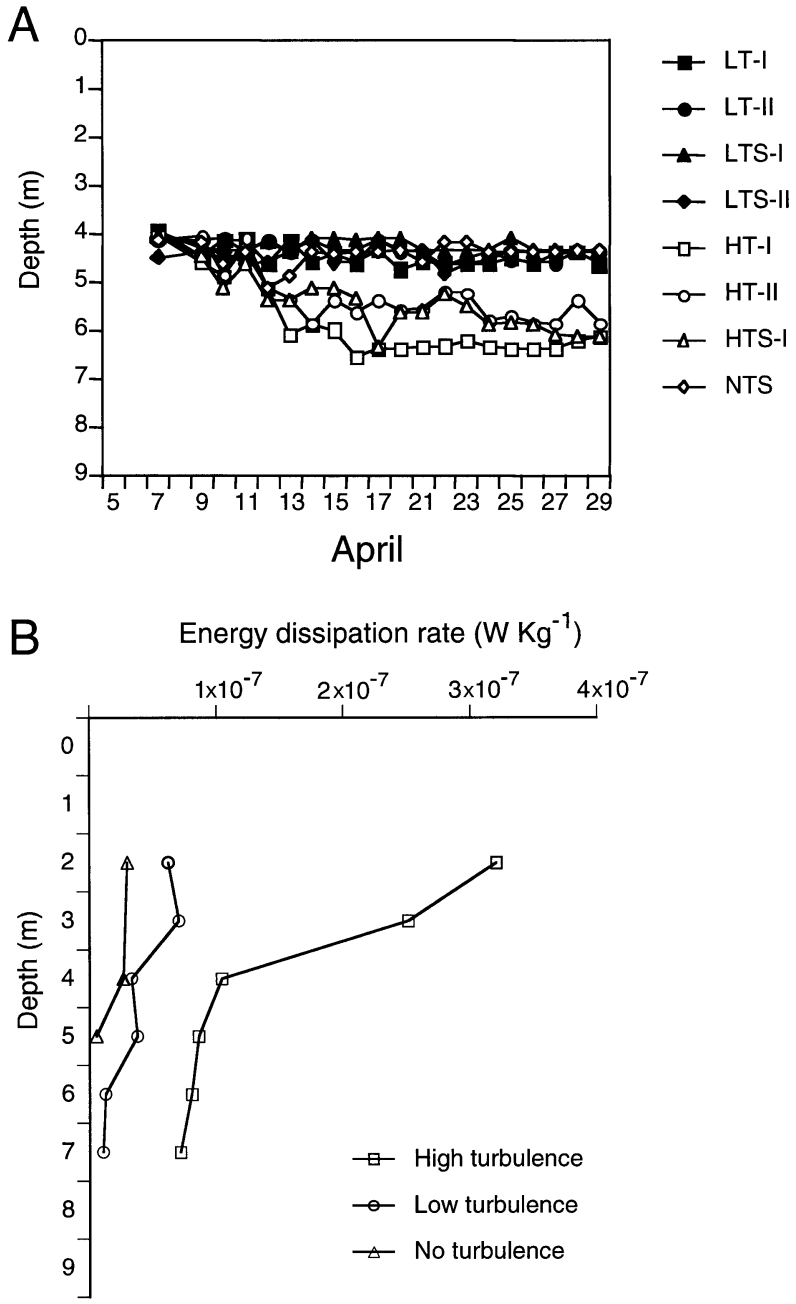

Fig. 3. (A) Depth (m) of pycnocline separating upper and lower layers in enclosures (see Table 1 for treatment designations). (B) Energy dissipation rates ( $\mathrm{W} \mathrm{kg}^{-1}$ ) as a function of depth for the 3 turbulence regimes (high, low and no turbulence generation). Enclosures with high turbulence were HT-I, HT-II and HTS-I; enclosures with low turbulence were LT-I, LT-II, LTS-I and LTS-II; NTS had no turbulence

between depths (2 and $6 \mathrm{~m}$ ) or enclosures (Fig. 4). After nutrient addition on 5 April, both nitrate and phosphate were more rapidly consumed in the silicateenriched enclosures (NPS) than in the non-silicate enclosures (NP) (Fig. 4). Except for peak values in NPS enclosures immediately after addition, silicate concentrations were generally low in all enclosures. Ammonium concentrations were low in all enclosures, on average $<0.8 \mu \mathrm{M}$ at $2 \mathrm{~m}$ and $<1.4 \mu \mathrm{M}$ at $6 \mathrm{~m}$ depth (S. Kristiansen unpubl. data).

Consumption of nitrate and phosphate was higher in NPS than in NP enclosures. On average the total consumption of nitrate and phosphate was 2.8 and $0.4 \mathrm{~g}$ $\mathrm{m}^{-2}$, respectively, in NPS, and 2.6 and $0.3 \mathrm{~g} \mathrm{~m}^{-2}$ for nitrate and phosphate in NP replicates (Table 3 ). Sili- 
cate was only added to NPS replicates, and on average consumption in these enclosures was $3.6 \mathrm{~g} \mathrm{~m}^{-2}$ (Table 3).

\section{Suspended material}

In the NP replicates (LT and HT), the primary production rate (Fig. 5) and biomass of chl a (Fig. 6) decreased during the first $10 \mathrm{~d}$ of the experiment. After this period both primary production rate and chl $a$ concentrations increased rapidly, with maximum concentrations occurring between 23 and 25 April. In the NP enclosures, chl a concentrations were approximately similar at 2 and $6 \mathrm{~m}$, while substantially higher chl a concentrations were present at $2 \mathrm{~m}$ than at $6 \mathrm{~m}$ in the NPS replicates (data not shown). POC concentrations in LT and HT followed, in general, the same trend as chl $a$, with an initial decrease followed by an increase at the end of the experiment (Fig. 7). In the NPS enclosures (LTS, HTS and NTS), both primary production rate (Fig. 5) and chl a concentrations (Fig. 6) increased rapidly after the first nutrient addition on 5 April. The primary production rate in these enclosures was variable throughout the experiment, although generally high compared to the initial rates before nutrient additions. The chl a maximum (integrated) occurred between 13 and 15 April in NPS replicates. Concentrations of POC were stable and high in

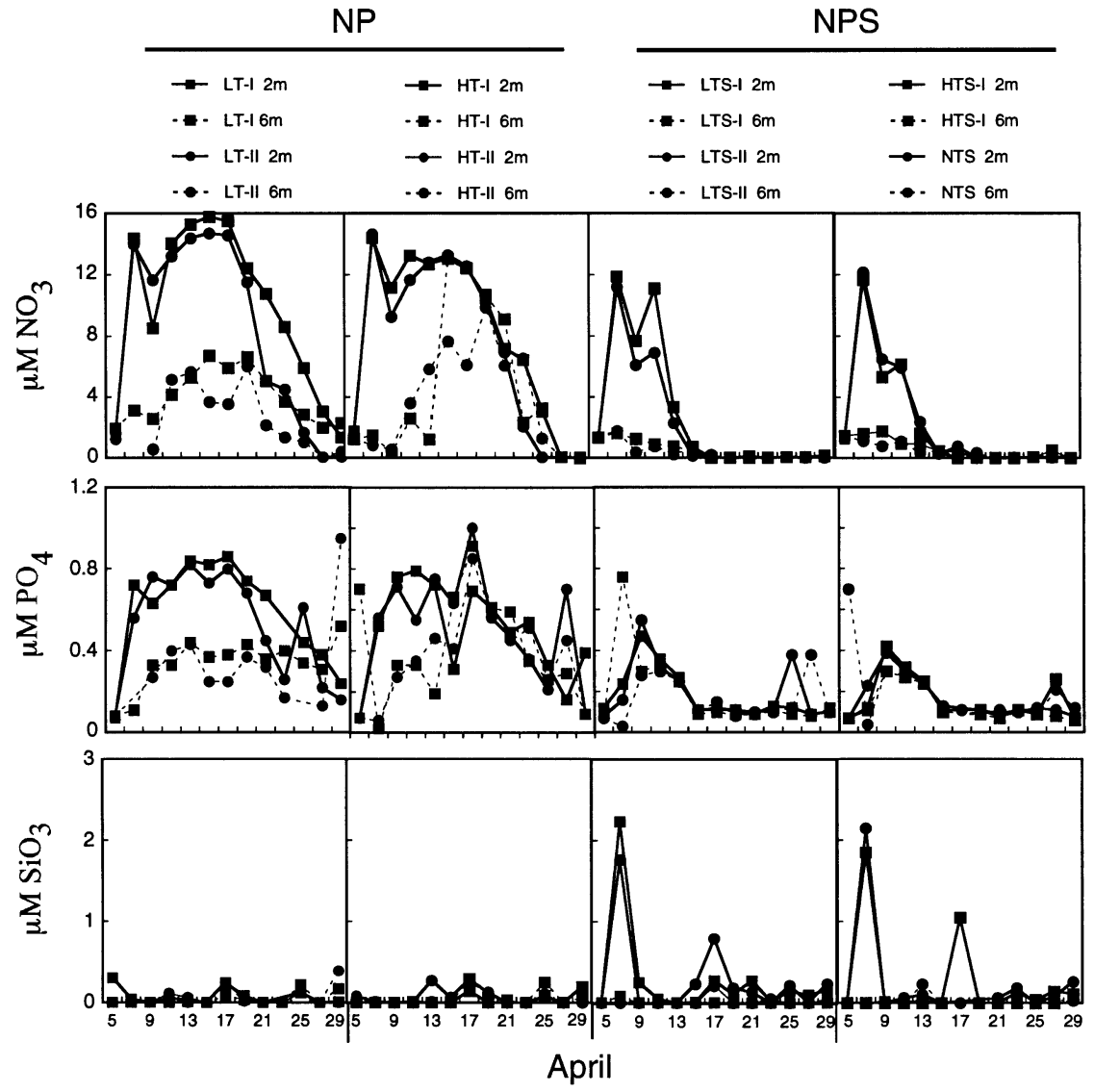

Fig. 4. Nutrient concentrations $(\mu \mathrm{M})$ in enclosures at 2 and $6 \mathrm{~m}$ depth (see Table 1)

Table 3. Carbon fixation, sedimentation of POC, PON and chl $a$ and nutrient consumption in all replicates calculated over the whole experimental period ( $24 \mathrm{~d}) .(\mathrm{a}: \mathrm{a}$, atomic ratio; w:w, weight ratio)

\begin{tabular}{|c|c|c|c|c|c|c|c|c|}
\hline & LT-I & LT-II & HT-I & HT-II & LTS-I & LTS-II & HTS-I & NTS \\
\hline $\mathrm{C}$ fixation $\left(\mathrm{g} \mathrm{C} \mathrm{m}^{-2}\right)$ & 5.7 & 6.7 & 8.7 & 7.8 & 11.0 & 10.4 & 11.3 & 10.1 \\
\hline DSi consumption (g DSi m ${ }^{-2}$ ) & 0.07 & - & 0.01 & 0.06 & 3.6 & 3.6 & 3.6 & 3.5 \\
\hline $\mathrm{N}$ consumption $\left(\mathrm{g} \mathrm{N} \mathrm{m}^{-2}\right)$ & 2.5 & 2.7 & 2.7 & 2.7 & 2.8 & 2.8 & 2.9 & 2.8 \\
\hline $\mathrm{P}$ consumption $\left(\mathrm{g} \mathrm{P} \mathrm{m}^{-2}\right)$ & 0.3 & 0.3 & 0.4 & 0.4 & 0.4 & 0.4 & 0.4 & 0.5 \\
\hline C fixation/DSi consumption (a:a) & 173 & - & 1708 & 285 & 7.2 & 6.7 & 7.4 & 6.8 \\
\hline C fixation/N consumption (a:a) & 2.6 & 2.9 & 3.7 & 3.3 & 4.5 & 4.2 & 4.6 & 4.1 \\
\hline $\mathrm{C}$ fixation/P consumption (a:a) & 49.0 & 51.5 & 53.0 & 52.8 & 70.1 & 69.1 & 73.5 & 56.0 \\
\hline POC sedimentation $\left(\mathrm{g} \mathrm{C} \mathrm{m}^{-2}\right)$ & 40.5 & 40.5 & 28.4 & 29.1 & 16.7 & 19.3 & 19.7 & 22.7 \\
\hline PON sedimentation $\left(\mathrm{g} \mathrm{N} \mathrm{m}^{-2}\right)$ & 6.4 & 6.6 & 4.7 & 4.5 & 2.6 & 2.9 & 3.1 & 3.5 \\
\hline Chl a sedimentation $\left(\mathrm{mg} \mathrm{chl} \mathrm{a} \mathrm{m}{ }^{-2}\right)$ & 598 & 641 & 515 & 469 & 174 & 187 & 209 & 227 \\
\hline POC sedimentation/PON sedimentation (a:a) & 7.3 & 7.1 & 7.0 & 7.5 & 7.5 & 7.6 & 7.4 & 7.6 \\
\hline POC sedimentation/Chl a sedimentation (w:w) & 67.7 & 63.2 & 55.1 & 62.0 & 100.0 & 103.2 & 94.2 & 100.0 \\
\hline
\end{tabular}




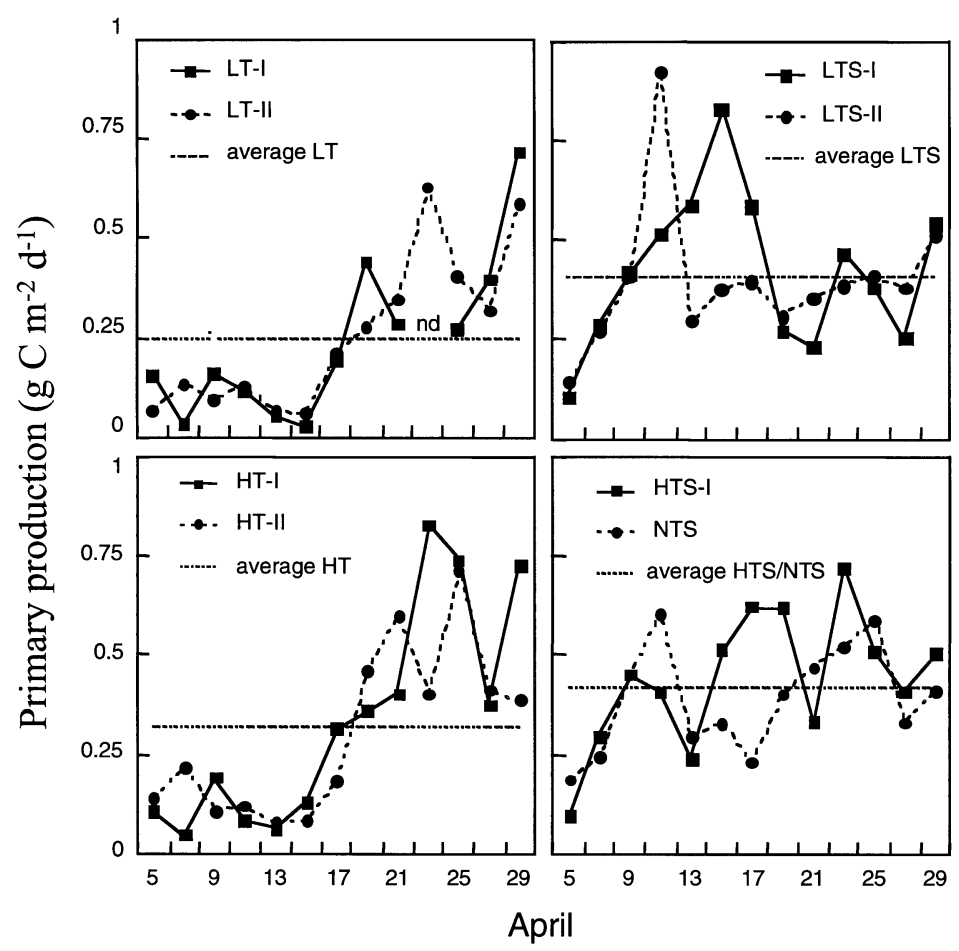

Fig. 5. Primary production $\left(\mathrm{g} \mathrm{C} \mathrm{m}^{-2} \mathrm{~d}^{-1}\right)$ during experiment. Values integrated to $8 \mathrm{~m}$ from measurements at 2 and $6 \mathrm{~m}$. Horizontal line indicates average production in 2 replicates with similar treatment (and for HTS-I and NTS)

The main difference in phytoplankton species composition between the treatments was the appearance of diatoms in the NPS enclosures while they were hardly present in NP replicates (Fig. 8). An ANOVA repeated measures confirmed that this difference due to nutrient additions was statistically significant $(F=96.6, \mathrm{p}<0.005)$. In the LTS replicates the diatoms grew rapidly from initial concentrations of ca $2 \times 10^{6}$ cells $^{-1}$ to maximum peaks of $8 \times 10^{6}$ cells $^{-1}$ on 17 April, while in HTS-I/NTS the peak occurred later (21 and 23 April, respectively). Chaetoceros socialis contributed 45 to $85 \%$ of the total abundance of diatoms (data not shown) and was thus the dominating species in all NPS replicates during the experiment. Turbulence had no effect on the abundance of diatoms or any other phytoplankton group in the enclosures (all $F<3.3, \mathrm{p}>0.2$ ).

Numerically, flagellates were the most abundant group, with a statistically significant higher abundance in NPS than in NP enclosures (ANOVA repeated measures, $F=24.3$, $\mathrm{p}<0.05$ ). A bloom of ca 20 to $25 \times 10^{6}$ cells $^{-1}$ developed on 21 April in NPS, and about half as many cells in the NP replicates (Fig. 8). The bloom was dominated by the small flagellates
Resultor mikron and Nephroselmis minuta (1.5 to 2.5 and $3.5 \mu \mathrm{m}$, respectively), which did not contribute much to biovolume (data not shown).

Phaeocystis pouchetii was present in approximately equal amounts ( 1 to $3 \times 10^{6}$ cells $\mathrm{l}^{-1}$ ) in all enclosures (Fig. 8). No statistical difference in abundance was found between enclosures, and there were no distinct bloom scenarios at $2 \mathrm{~m}$ depth. Dinoflagellates showed a slight numerical increase from the beginning to end of April (Fig. 8), with no statistically significant difference between treatments.

\section{Vertical flux}

The higher rates of suspended biomass ( $\operatorname{chl} a$ ) and primary production in NPS compared to NP did not lead to increased sedimentation rates of chl $a$. Sedimentation of chl $a$ in all NPS treatments was stable and $<15 \mathrm{mg} \mathrm{m}^{-2} \mathrm{~d}^{-1}$ for all turbulence regimes (Fig. 9), with mean values of 7 and $9 \mathrm{mg} \mathrm{m}^{-2} \mathrm{~d}^{-1}$ for LTS and HTS, respectively (Table 4). The bloom that developed during the first week of the experiment and declined during the third week was not

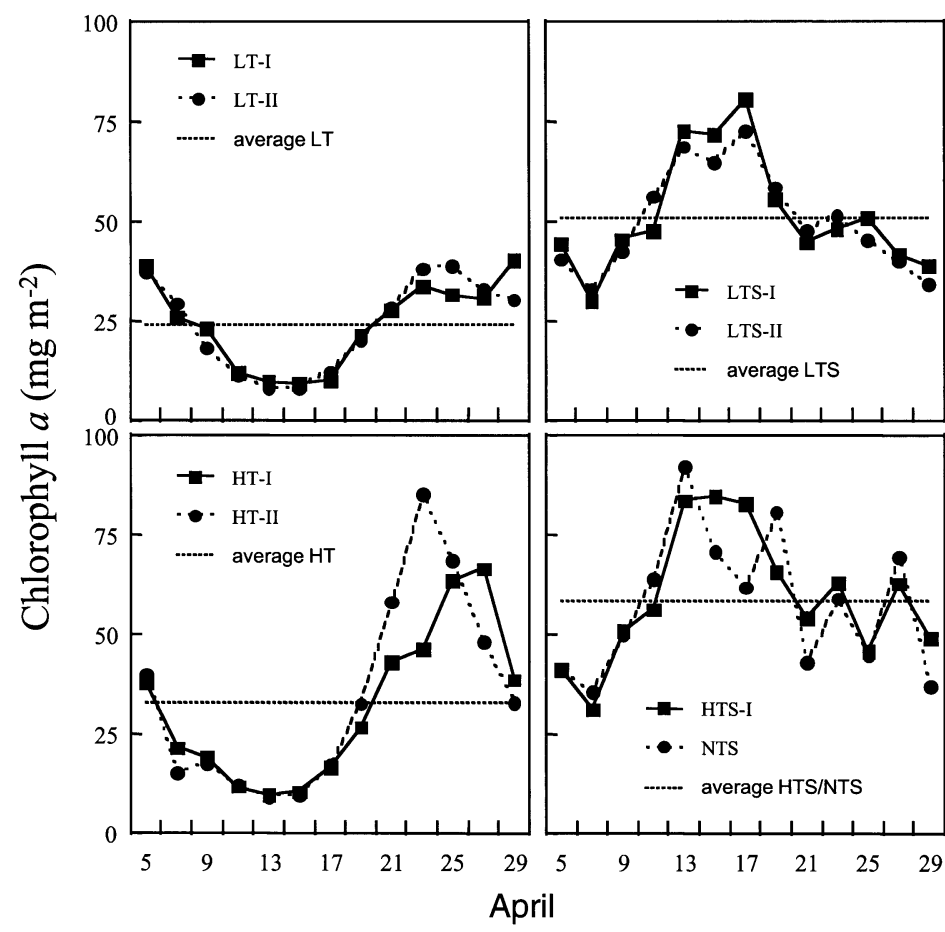

Fig. 6. Suspended chlorophyll a $\left(\mathrm{mg} \mathrm{m}^{-2}\right)$ in different enclosures. Values integrated to $8 \mathrm{~m}$. Measurements at $2 \mathrm{~m}$ represent upper part of enclosures and those at $6 \mathrm{~m}$ represent lower part. Horizontal line as for Fig. 5 


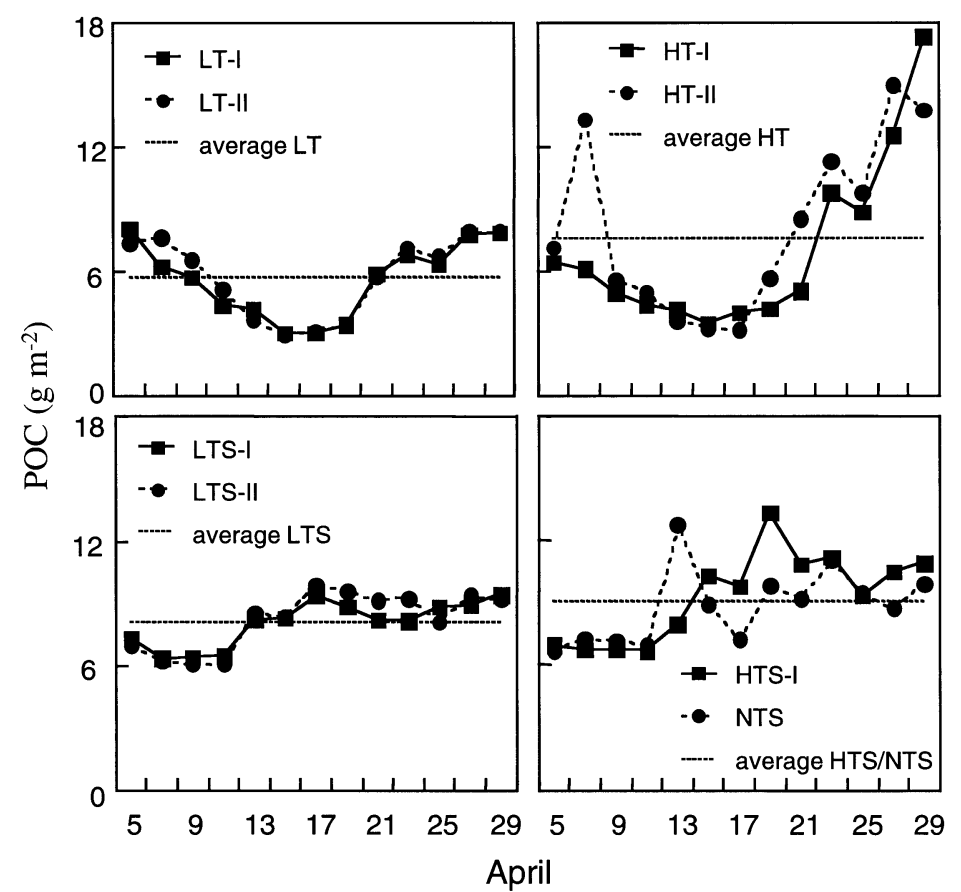

Fig. 7. Suspended particulate organic carbon $\left(\mathrm{g} \mathrm{POC}^{-2}\right)$ in enclosures. Integrations as calculated for $\mathrm{chl} a$
In the NPS replicates, sedimentation of POC was around $1 \mathrm{~g} \mathrm{~m}^{-2} \mathrm{~d}^{-1}$, with little variation throughout the experiment (Fig. 10). Significantly more POC sedimented in the NP than in the NPS enclosures (ANOVA repeated measures, $F=9.1, \mathrm{p}=0.05)$, although POC flux was more or less similar in NP and NPS replicates from 7 to 17 April. Thereafter, the NP replicates experienced a sharp increase in settling carbon.

In LT-I and HT-I, maximum sedimentation of diatoms (in terms of cells) occurred from 7 to 15 April, while in LTS-I and HTS-I the sedimentation of diatoms increased from 1 to $4 \times 10^{9}$ cells $\mathrm{m}^{-2} \mathrm{~d}^{-1}$ between 11 and 23 April (Fig. 11). Flagellates and Phaeocystis pouchetii (single and colonial cells) settled in increasing amounts towards the end of the experiment in LT-I and HT-I, while sedimentation rates were low in LTS-I and HTS-I (Fig. 11). Generally, for all enclosures, faecal pellets were relatively unimportant for POC sedimentation (Fig. 10).

Where data are available, the relative contribution of PPC to the settled POC ranged between 5.3 and $54.6 \%$ (Fig. 10), but the com- detectable in the sediment traps in LTS and HTS enclosures. In LT and HT enclosures, however, average sedimented chl a was high; 28 and $22 \mathrm{mg} \mathrm{m}^{-2} \mathrm{~d}^{-1}$, respectively (Table 4). The high average sedimentation in LT and HT was a result of a steep increase in sedimented chl a that reached ca $100 \mathrm{mg} \mathrm{m}^{-2} \mathrm{~d}^{-1}$ in the LT replicates, and about $80 \mathrm{mg}$ $\mathrm{m}^{-2} \mathrm{~d}^{-1}$ in the $2 \mathrm{HT}$ enclosures (Fig. 9). There was no significant difference between the LT and HT enclosures or between the LTS and HTS enclosures (ANOVA repeated measures, $F=$ $4.3, \mathrm{p}>0.05)$, meaning that the 2 turbulence regimes had no effect on the loss of chl a from the enclosures. Neither did we find any interaction effect between nutrients and turbulence.

Fig. 8. Numerical abundance and development of diatoms, dinoflagellates, flagellates and Phaeocystis pouchetii in enclosures. Samples from $2 \mathrm{~m}$ depth. Note different scales on $y$-axes

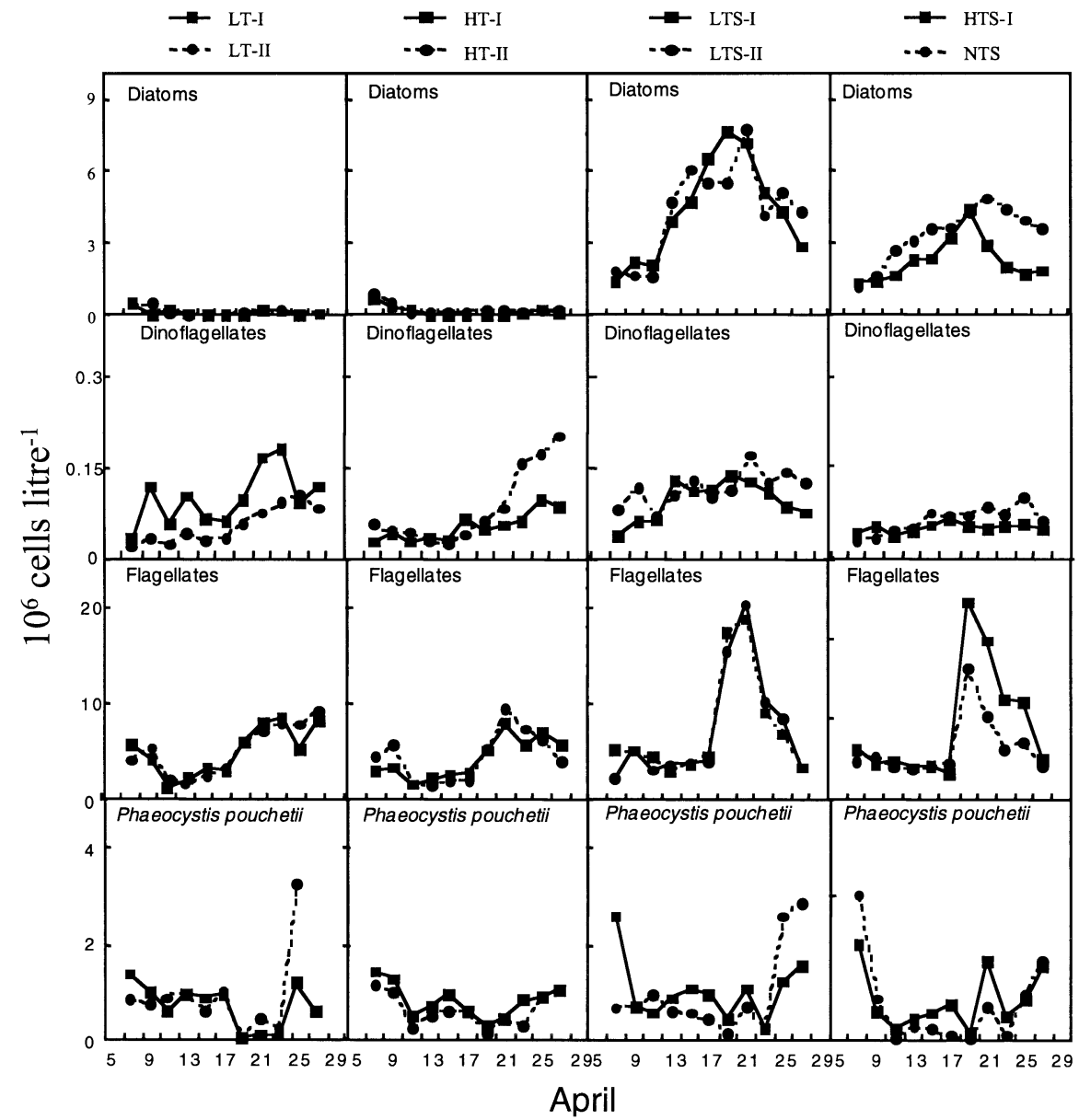




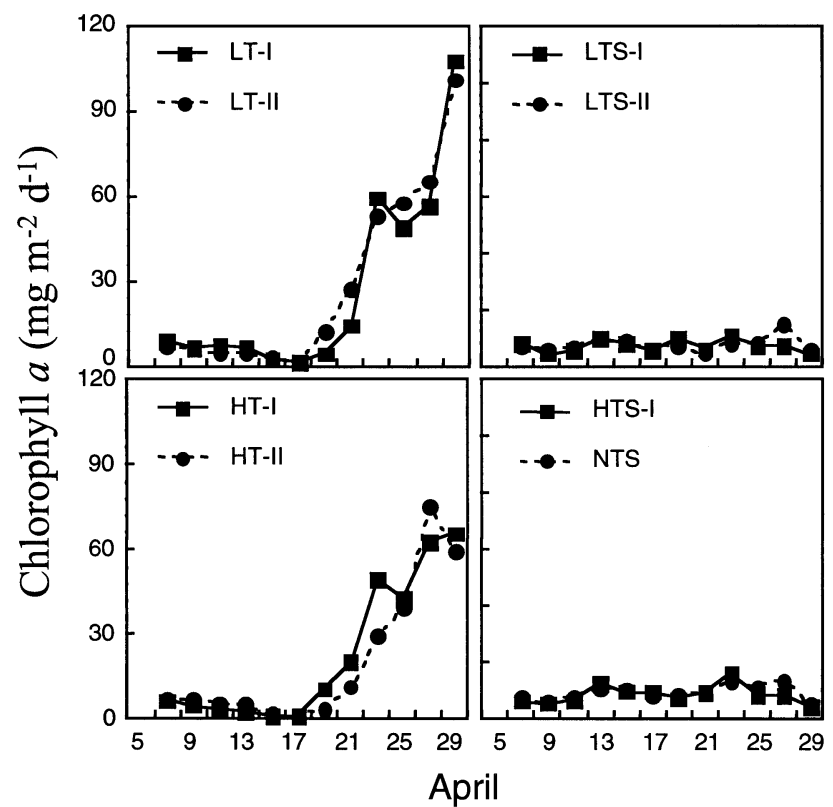

Fig. 9. Daily sedimentation rates of chl a $\left(\mathrm{mg} \mathrm{m}^{-2} \mathrm{~d}^{-1}\right)$ in the enclosures

position of PPC itself was highly variable between the treatments. On average, diatoms contributed 86 and $89 \%$ of total PPC in LTS-I and HTS-I, respectively (Fig. 12). In LT-I and HT-I, however, the composition of PPC was much more variable, and can be divided into the same 2 periods as sedimented POC. During the first period ( 7 to 15 April), the composition of sedimented PPC was characterised by a gradual decrease of diatoms and dinoflagellates. During the second period (19 to 29 April), Phaeocystis sp. cell carbon contributed $80 \%$ both in LT-I and HT-I.

Table 4. Suspended and sedimented chlorophyll a (chl a), particulate organic carbon (POC) and particulate organic nitrogen (PON). All values are averages $( \pm \mathrm{SD})$ of 2 replicates, except for maximum sedimentation (max. sed.) which is the highest sedimentation rate found in 1 replicate. Dominating photoplankton groups were determined according to cells per litre in upper part of enclosures

\begin{tabular}{|lcccc|}
\hline & $\begin{array}{c}\text { LT-I } \\
\text { LT-II }\end{array}$ & $\begin{array}{c}\text { LTS-I } \\
\text { LTS-II }\end{array}$ & $\begin{array}{c}\text { HT-I } \\
\text { HT-II }\end{array}$ & $\begin{array}{c}\text { HTS-I } \\
\text { NTS }\end{array}$ \\
\hline $\begin{array}{cccc}\text { Dominating photo- } \\
\text { plankton group }\end{array}$ & Flagellates & $\begin{array}{c}\text { Diatoms/ } \\
\text { Flagellates }\end{array}$ & Flagellates & $\begin{array}{c}\text { Diatoms/ } \\
\text { Flagellates }\end{array}$ \\
Chl a & & & & \\
Integrated $\left(\mathrm{mg} \mathrm{m}^{-2}\right)$ & $24 \pm 11$ & $51 \pm 14$ & $33 \pm 22$ & $58 \pm 17$ \\
Sedimented $\left(\mathrm{mg} \mathrm{m}^{-2} \mathrm{~d}^{-1}\right)$ & $28 \pm 32$ & $7 \pm 2$ & $22 \pm 25$ & $9 \pm 3$ \\
Max. sed. $\left(\mathrm{mg} \mathrm{m}^{-2} \mathrm{~d}^{-1}\right)$ & 107.7 & 14.6 & 75.4 & 13.3 \\
& & & & \\
POC & $5.7 \pm 1.8$ & $8.2 \pm 1.2$ & $7.5 \pm 4.1$ & $9.1 \pm 1.9$ \\
Integrated $\left(\mathrm{g} \mathrm{m}^{-2}\right)$ & $1.8 \pm 1.6$ & $0.7 \pm 0.3$ & $1.2 \pm 1.0$ & $0.9 \pm 0.3$ \\
Sedimented $\left(\mathrm{g} \mathrm{m}^{-2} \mathrm{~d}^{-1}\right)$ & & & & \\
PON & $0.9 \pm 0.2$ & $1.3 \pm 0.2$ & $1.1 \pm 0.5$ & $1.4 \pm 0.3$ \\
Integrated $\left(\mathrm{g} \mathrm{m}^{-2}\right)$ & $0.3 \pm 0.2$ & $0.1 \pm 0.04$ & $0.2 \pm 0.2$ & $0.1 \pm 0.04$ \\
Sedimented $\left(\mathrm{g} \mathrm{m}^{-2} \mathrm{~d}^{-1}\right)$ & & & & \\
\hline
\end{tabular}

\section{DISCUSSION}

To the best of our knowledge, the present mesocosm experiment is the first to combine turbulence and measurements of vertical flux of biogenic matter. We succeeded in creating a more stagnant layer below the upper part of the enclosures where turbulence was generated (Table 2), thus making sedimentation measurements possible. The dissipation rates generated correspond well to measurements in other mesocosm experiments with turbulence generation (Petersen et al. 1998), and lie within typical turbulent intensities $O\left(10^{-9} \mathrm{~W} \mathrm{~kg}^{-1}\right)$ found in the upper mixed layer in the sea (Oakey \& Elliott 1980). However, the dissipation rates between the high and low turbulence replicates differed less than intended, due to the high 'background' turbulence. An experiment running parallel to ours, using only airlift to mix a $6 \mathrm{~m}$ deep enclosure, had an average energy dissipation rate of $8.3 \times 10^{-8} \mathrm{~W}$ $\mathrm{kg}^{-1}$ (S. Nerheim pers. comm.). It appears problematic to carry out experiments in enclosures with flexible walls in the ocean with turbulence intensities lower than $O\left(10^{-9} \mathrm{~W} \mathrm{~kg}^{-1}\right)$, and other mesocosm experiments with similar flexible wall enclosures should take this into account when analysing the data. It should also be mentioned that flexible wall enclosures may cause focusing of material into the sediment traps (Wassmann et al. 1996). Therefore, differences between enclosures and responses to treatments are of more interest than absolute sedimentation rates in this experiment.

\section{Effect of silicate and turbulence on diatoms}

The present study shows that DSi addition created a substantial shift in the flagellate-dominated phytoplankton community to a diatom-dominated one. Buoyancy regulation in diatoms is very sensitive to Si-deprivation (Bienfang et al. 1982), and in the NP replicates the diatoms sank out rapidly, probably as a result of $\mathrm{Si}$ depletion. In NPS, the diatoms did show a sinking potential by making up 80 to $100 \%$ of sedimented PPC in the NPS replicates (Fig. 12), although in terms of carbon the sedimentation rates were surprisingly much higher in NP than in NPS.

We expected high sedimentation of diatoms in the highly turbulent, diatom-dominated enclosures (hypo- 


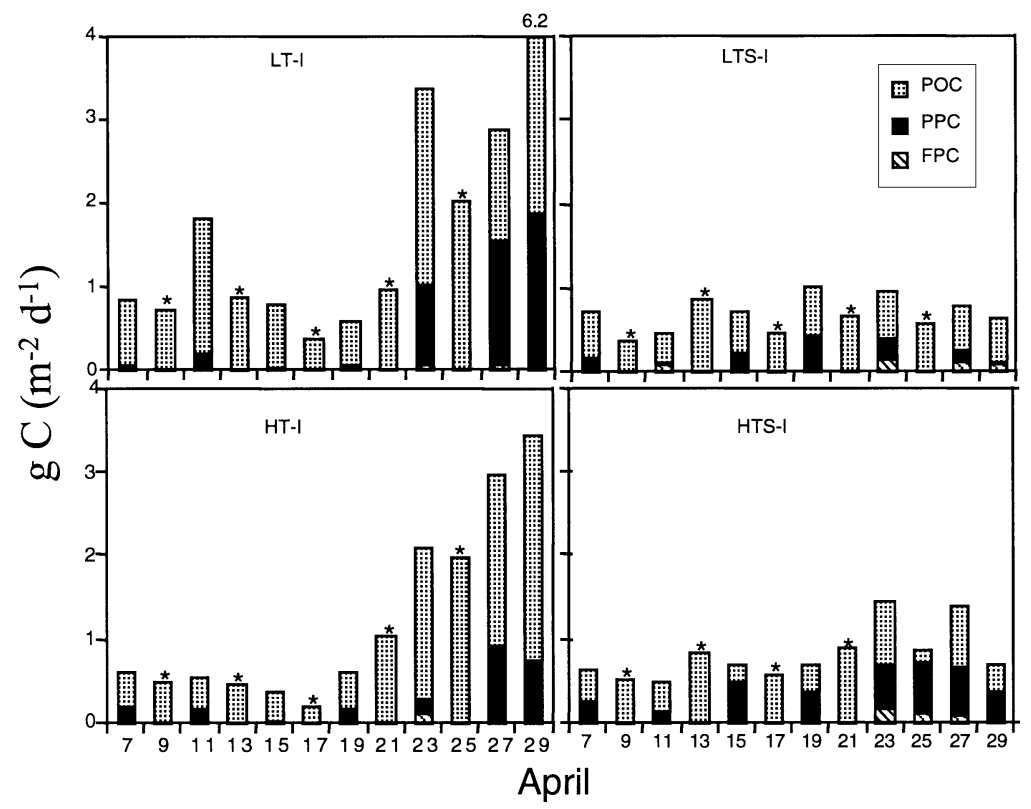

Fig. 10. Daily sedimentation rates $\left(\mathrm{g} \mathrm{m}^{-2} \mathrm{~d}^{-1}\right)$ of particulate organic carbon (POC) and contribution of phytoplankton carbon (PPC) and faecal pellet carbon (FPC) in LT-I, HT-I, LTS-I and HTS-I. Asterisks above bars indicate where phytoplankton samples were not available for calculation of PPC and FPC

changes in cell numbers in the LTS-I enclosure from 9 to 19 April, because $C$. socialis appeared to grow exponentially during this period. Shear rate was calculated from turbulent energy dissipation rates $\left(\varepsilon, \mathrm{m}^{2} \mathrm{~s}^{-3}\right)$ from the high, low and non-turbulent enclosure(s), using the equation $\gamma=(\varepsilon / v)^{0.5}$ (Alldredge et al. 1990), where $v$ is kinematic viscosity $\left(10^{-6} \mathrm{~m}^{2} \mathrm{~s}^{-1}\right)$. Particle diameter $($ C. socialis,

theses 1 and 3) based on coagulation theory for phytoplankton (McCave 1984, Jackson 1990, Kiørboe 1997). As explained by the theory, coagulation of diatoms into aggregates by collision of particles is directly proportional to the shear rate, the size and the coagulation efficiency of the particles. This means that loss of particles from the euphotic zone by coagulation can be determined by an upper limit of cell concentration during a bloom (e.g. Dam \& Drapeau 1995), and that this upper limit is dependent on the turbulence in the system. When the highest abundance of diatoms was found in the LTS replicates, we wanted to examine whether this was a result of different critical concentrations (Kiørboe et al. 1994, Tiselius \& Kuylenstierna 1996) caused by the different turbulence regimes in LTS, HTS and NTS replicates (see Table 2).

We calculated critical concentrations for the dominating diatom species, Chaetoceros socialis, at $2 \mathrm{~m}$ for all NPS enclosures according to the equation first given by Jackson (1990): $C_{\mathrm{cr}}=$ $0.384 \mu / \alpha \gamma d^{3}$, where $\mu$ is net (accumulation - losses) particle growth rate $\left(\mathrm{s}^{-1}\right)$, $\alpha$ is the particle stickiness, $\gamma$ is the fluid shear rate $\left(\mathrm{s}^{-1}\right)$ and $d$ is the diameter $(\mathrm{cm})$ of the particle. The growth rate was calculated from the observed

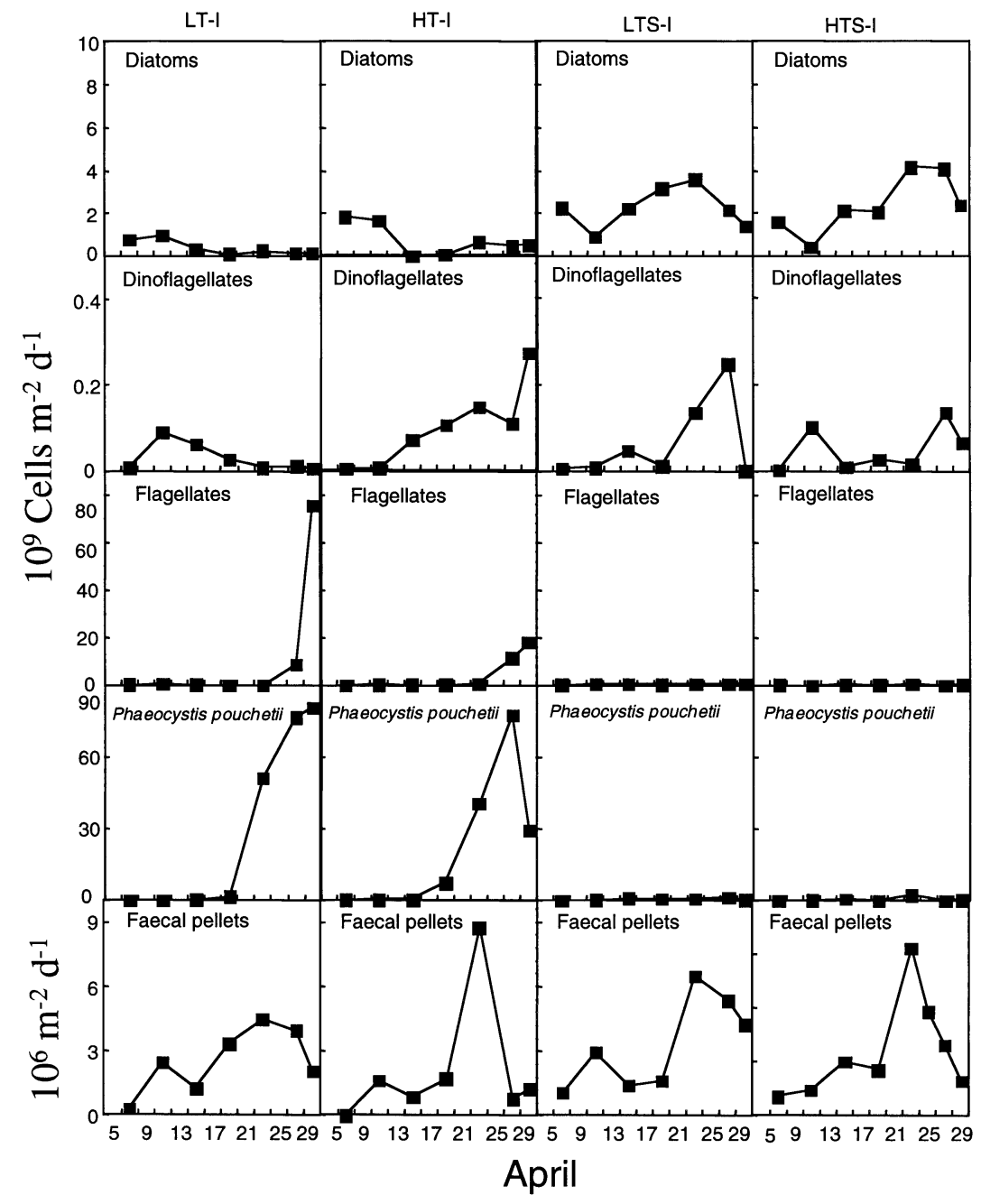

Fig. 11. Daily sedimentation rates of dominating phytoplankton groups and faecal pellets in LT-I, HT-I, LTS-I and HTS-I 
LT-I

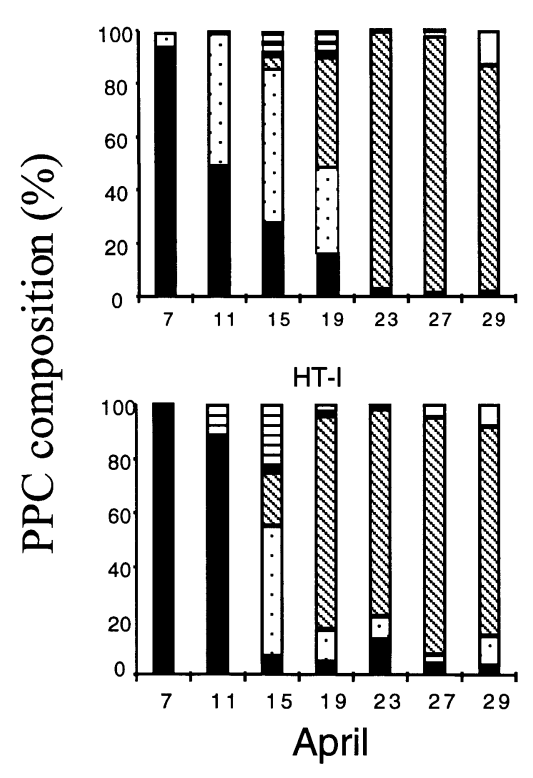

Fig. 12. Relative contribution (\%) of sedimentation rates of different phytoplankton groups and Phaeocystis pouchetii to phytoplankton carbon (PPC) in LT-I, HT-I, LTS-I and HTS-I
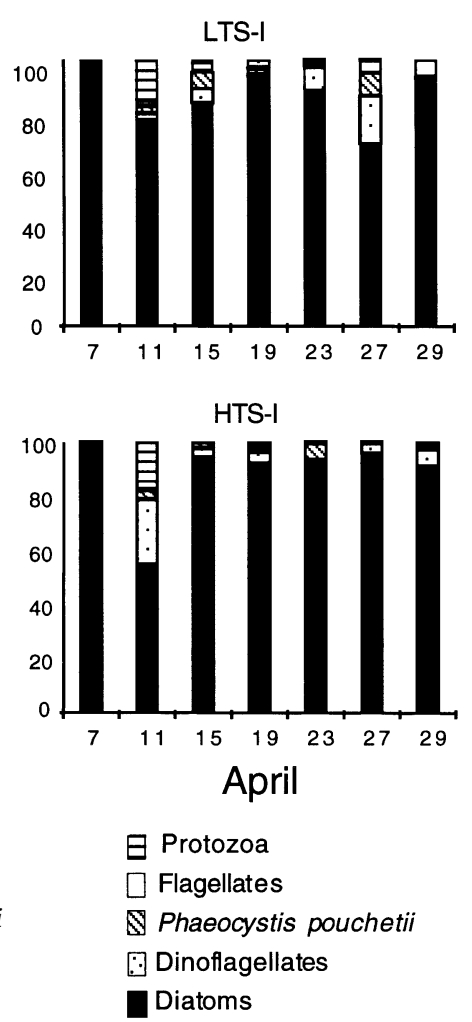

$>10^{-4} \mathrm{~W} \mathrm{~kg}^{-1}$ to disaggregate (Alldredge et al. 1990). The highest energy dissipation rates measured in this experiment lie at the lower end of the reported range, and hence it is difficult to quantify the impact on aggregate break-up. However, since the dissipation rates reported here are average values, it is possible to speculate that some disaggregation could have occurred in the upper layer of all enclosures, for instance on windy days. On the other hand, the turbulence generated in our enclosures was probably not strong enough to break apart any aggregates of detrital debris or aggregates of living bacteria, as they have been reported to resist dissipation rates $\gg 10^{-4} \mathrm{~W}$ $\mathrm{kg}^{-1}$ (Alldredge et al. 1990). The rather narrow range of dissipation rates in all enclosures (Table 2) could also be the reason why no statistically significant difference in diatom sedimentation was found between the different turbulence regimes.

As the sedimentation rates of diatoms in general were low and constant, the decline of the bloom around 17 April was probably caused by grazing. The microzooplankton single cell) was estimated from particle volume, assuming spherical shape.

The calculated $C_{\mathrm{cr}}$ for Chaetoceros socialis showed that this species never reached concentrations high enough to form aggregates in LTS-I, LTS-II and HTS-I (Table 5). A number of crude approximations were made in the calculations, as for instance assuming a stickiness of 0.15 , although $\alpha$ may be species dependent and also variable in time (Dam \& Drapeau 1995). Nevertheless, the result gives an indication that the bloom of $C$. socialis was probably not ended exclusively by aggregate formation followed by sedimentation. Because this species dominated the development of the diatoms as a group, this conclusion is most likely also the case for the other diatoms in the experiment. However, it has been reported that fragile aggregates of diatoms need energy dissipation rates of $10^{-7}$ to

Table 5. Calculated critical concentrations $\left(C_{\mathrm{cr}}\right)$ of Chaetoceros socialis and observed maximum concentrations $\left(C_{\max }\right)$ in the 4 silicate enriched enclosures

\begin{tabular}{|lccccc|}
\hline & $\begin{array}{c}\text { Shear } \\
\left(\mathrm{s}^{-1}\right)\end{array}$ & $\begin{array}{c}\text { Growth } \\
\text { rate }\left(\mathrm{d}^{-1}\right)\end{array}$ & $\begin{array}{c}\text { Diameter } \\
(\mu \mathrm{m})\end{array}$ & \multicolumn{2}{c|}{$\begin{array}{c}C_{\mathrm{cr}} \\
\left(10^{6} \text { cells }^{-1}\right)\end{array}$} \\
\hline LTS-I & 0.23 & 0.21 & 5.8 & 136 & 7 \\
LTS-II & 0.23 & 0.21 & 5.8 & 136 & 6 \\
HTS-I & 0.43 & 0.21 & 5.8 & 73 & 4 \\
NTS & 0.17 & 0.21 & 5.8 & 191 & 4 \\
\hline
\end{tabular}

community (mainly composed of dinoflagellates and ciliates $>30 \mu \mathrm{m}$ equivalent spherical diameter, ESD) showed high grazing rates on phytoplankton (Nejstgaard et al. unpubl. data). Both dinoflagellates (Hansen et al. 1994) and large ciliates (J. Nejstgaard pers. comm.) may feed on chains of diatoms, and specific grazing experiments from one of the enclosures (LTS-I) demonstrated that the microzooplankton grazed diatoms corresponding to $24-42 \%$ of the standing stock per day (Nejstgaard et al. unpubl. data). In this experiment, total concentrations of zooplankton $>90 \mu \mathrm{m}$ increased from initial concentrations of about $10 \mathrm{mg} \mathrm{C} \mathrm{m}^{-3}$ to between 30 and $100 \mathrm{mg} \mathrm{C} \mathrm{m}^{-3}$ in NP replicates and between 40 and $60 \mathrm{mg} \mathrm{C} \mathrm{m}^{-3}$ in NPS replicates (Nejstgaard pers comm.). In all enclosures Calanus finmarchicus was the dominating copepod, and fed selectively on the microzooplankton. It is therefore likely that the phytoplankton stock could be regulated indirectly by mesozooplankton predation through a trophic cascade effect as previously shown in 25-1 bottle experiments (Nejstgaard et al. 1997). As the average concentration of mesozooplankton was higher in NP than in NPS, it is likely that phytoplankton were more heavily grazed by microzooplankton in NPS enclosures.

To summarise, the addition of DSi did favour the growth of diatoms as hypothesised, but did not increase the vertical flux of biogenic matter. The different levels of turbulence did not cause variation in 
vertical flux of diatoms, probably because the diatoms never reached concentrations high enough to create rapidly sinking aggregates. It may seem that the effects of turbulence are coupled to processes other than coagulation of diatom cells in this experiment.

\section{Contribution of Phaeocystis pouchetii}

The sedimentation rate of Phaeocystis pouchetii cells in LT-I and HT-I (between 80 and $90 \times 10^{9}$ cells m$^{-2} \mathrm{~d}^{-1}$ ) is, to our knowledge, among the highest reported for Phaeocystis sp., only exceeded by a previous mesocosm experiment at the same locality with sedimentation rates up to $400 \times 10^{9}$ cells m${ }^{-2} \mathrm{~d}^{-1}$ (Christensen 1998). None of our enclosures indicated increased abundance or higher sedimentation rates of P. pouchetii caused by elevated energy dissipation rates. However, other mesocosm studies have demonstrated that Phaeocystis sp. obtained higher biomass in mesocosms with a high mixing rate (Escaravage et al. 1998, Jacobsen 2000). The lack of difference in P. pouchetii biomass among the treatments (both nutrients and turbulence) in our experiment could be a result of poor resolution in phytoplankton sampling (1 sample at $2 \mathrm{~m}$ ). The high sedimentation rates in the NP replicates and high chl a concentrations at $6 \mathrm{~m}$ (not found in NPS replicates) indicate a high biomass of $P$. pouchetii in the deeper part of the enclosures, i.e. below the mixed layer. Temperatures $<10^{\circ} \mathrm{C}$, incident irradiance $<20 \mathrm{~mol} \mathrm{~m}^{-2} \mathrm{~d}^{-1}$ and $\mathrm{N}$ and $\mathrm{P}$ present in respective concentrations of $>5$ and $>0.2 \mu \mathrm{M}$ are reported to be optimal conditions for colonial growth (Jacobsen 2000). These requirements were met at $6 \mathrm{~m}$ depth in the NP enclosures. Growth below $2 \mathrm{~m}$ depth is probably also the reason why calculated loss rates from the upper layer are unrealistically high (and therefore highly questionable). A better spatial resolution of phytoplankton sampling should therefore be considered in future mesocosm studies.

Mass sedimentation of Phaeocystis sp. is not only a mesocosm phenomenon, but has also been reported in situ (Wassmann et al. 1990, Wassmann 1994, M. Reigstad et al. pers. comm.). Common to these studies is the fact that Phaeocystis cells sank in relatively large numbers (up to $7 \times 10^{9}$ cells $\mathrm{m}^{-2} \mathrm{~d}^{-1}$ at $40 \mathrm{~m}$ in the Barents Sea) in sediment traps in shallow water, while its contribution rapidly declined with depth (Lutter et al. 1989, Wassmann 1994). In a northern Norwegian fjord, $<15 \%$ of the Phaeocystis found at $10 \mathrm{~m}$ was found to sink to $50 \mathrm{~m}$ depth or deeper (Lutter et al. 1989). Frequently suggested explanations for the disappearance of Phaeocystis cells and colonies at greater depths are cell lysis and rapid remineralisation, so that Phaeocystis enters the microbial loop instead of the more classi- cal food chain (Fernandez et al. 1992). Growth of $P$. pouchetii in the traps does not explain the increased sedimentation rates observed towards the end of the experiment. Neither does it explain differences in sedimentation rates between NP and NPS enclosures.

It has recently been documented that ageing and partly dissolved colonies of Phaeocystis produce transparent exopolymer particles (TEP, see Alldredge et al. 1993, Passow 2000), attract bacteria and flagellates and form dense aggregates scavenging the water column (M. Reigstad et al. pers. comm.). TEP production has thus been suggested to be an important pathway for $P$. pouchetii carbon to reach deep waters (Reigstad et al. unpubl. data). Verity et al. (1988) also suggested that the gelatinous matrix of the colonies may be a good substrate for bacterial metabolism, and found that bacteria concentrations were elevated on 'ghost colonies'. This may provide attractive feeding grounds for heterotrophic flagellates (Reigstad et al. submitted). When the flagellate abundance increases the density of particles, aggregate formation and probably also the sinking velocity increases (P. Wassmann, pers. comm.). This corresponds well with our data, as sedimentation rates of flagellates increased in concert with P. pouchetii in LT-I and HT-I (Fig. 11). Although TEP was unfortunately not measured during this study, we suggest that the mass-sedimentation observed in the NP enclosures at the end of the experiment was a result of coagulation of senescent $P$. pouchetii colonies combined with low degradation in the sediment traps.

\section{Concluding remark}

When the NP and NPS enclosures are compared with regard to DSi consumption, carbon fixation and carbon export, it becomes evident that increased DSi consumption does not necessarily increase the vertical export of carbon (Table 3). Furthermore, by processes not yet fully understood, Phaeocystis pouchetii may contribute more than expected to the vertical flux, possibly by involving turbulence-resistant aggregates. Thus, this study does not support the suggested positive linear relationship between DSi consumption and carbon export suggested by Wassmann et al. (1996). It seems that for the time being, we do not have enough knowledge about how DSi will affect the various pathways in the food web.

Acknowledgements. The authors thank A. Sazhin and O. Sergeeva for phytoplankton analysis, S. Øygarden for C/N analysis, J. C. Nejstgaard for information on zooplankton and our co-workers on NAPP for stimulating co-operation. The criticism and comments of H. G. Dam, A.-S. Heiskanen, K. Olli, M. Reigstad and T. Tamminen are gratefully acknowledged. P. Wassmann contributed with valuable discussions, 
comments and advice during various phases of this work. M. Mauritzen provided helpful advice with statistical analyses. This investigation was supported by the Norwegian Research Council (NFR) and is a contribution of the Norwegian Programme Nutrients and Pelagic Marine Production (NAPP).

\section{LITERATURE CITED}

Alldredge AL, Granata TC, Gotschalk CC, Dickey TD (1990) The physical strength of marine snow and its implications for particle disaggregation in the ocean. Limnol Oceanogr 35:1415-1428

Alldredge AL, Passow U, Logan BE (1993) The abundance and significance of a class of large, transparent organic particles in the ocean. Deep-Sea Res 40:1131-1140

Bienfang PK, Harrison PJ, Quarmby LM (1982) Sinking rate response to depletion of nitrate, phosphate and silicate in four marine diatoms. Mar Biol 67:295-302

Christensen G (1998) The effect of different nutrient regimes on phytoplankton community and vertical flux in a mesocosm experiment. MSc thesis, University of Bergen (in Norwegian)

Dam HG, Drapeau DT (1995) Coagulation efficiency, organicmatter glues and the dynamics of particles during a phytoplankton bloom in a mesocosm study. Deep-Sea Res II 42: 111-123

Egge JK (1993) Nutrient control of phytoplankton growth: effects of macronutrient composition (N, P, Si) on species succession. Dr Scient. thesis, University of Bergen

Egge JK, Aksnes DL (1992) Silicate as regulating nutrient in phytoplankton competition. Mar Ecol Prog Ser 83:281-289

Escaravage V, Prins TC, Wetsteyn LPMJ, Peeters JCH (eds) (1998) Effects of water column structure and nutrient loading on plankton development. The impact of marine eutrophication on phytoplankton, zooplankton and benthic suspension feeders. Progress report: effects of stratification on plankton dynamics. Rijksinstituut voor Kust en Zee/RIKZ, Middelburg

Fernandez E, Serret P, de Madariaga I, Harbour DS, Davies AG (1992) Photosynthetic carbon metabolism and biochemical composition of spring phytoplankton assemblages enclosed in microcosms: the diatom-Phaeocystis sp. succession. Mar Ecol Prog Ser 90:89-102

Gargas E (ed) (1975) A manual for phytoplankton primary production studies in the Baltic, 2nd edn. Water Quality Institute, Høsholm

Garrison DL, Buck KR (1989) Protozooplankton in the Weddel Sea, Antarctica: abundance and distribution in the iceedge zone. J Polar Biol 9:341-351

Hansen B, Bjørnsen PK, Hansen PJ (1994) The size ratio between planktonic predators and their prey. Limnol Oceanogr 39:395-403

Jackson G (1990) A model of the formation of marine algal flocs by physical coagulation processes. Deep-Sea Res 37: $1197-1211$

Jacobsen A (2000) New aspects of bloom dynamics of Phaeocystis pouchetii (Haptophyta) in Norwegian waters. Dr Scient. thesis, University of Bergen

Jacobsen A, Egge JK, Heimdal B (1995) Effects of increased concentration on nitrate and phosphate during a springbloom experiment in mesocosm. J Exp Mar Biol Ecol 187: $239-251$

Kiørboe T (1993) Turbulence, phytoplankton cell size, and the structure of pelagic food webs. Adv Mar Biol 29:2-72

Kiørboe T (1997) Small-scale turbulence, marine snow formation, and planktivorous feeding. Sci Mar 61:141-158
Kiørboe T, Lundsgaard C, Olesen M, Hansen JSL (1994) Aggregation and sedimentation processes during a spring phytoplankton bloom: A field experiment to test coagulation theory. J Mar Res 52:297-323

Kraus NC, Lohrman A, Cabrera R (1994) New acoustic meter for measuring 3D laboratory flows. J Hydraulic Eng 120: 406-412

Lee C, Wakeham SG, Hedges JI (1988) The measurement of oceanic particle flux - are 'swimmers' a problem? Oceanography 1:34-36

Lutter S, Taasen JP, Hopkins CCE, Smetacek V (1989) Phytoplankton dynamics and sedimentation processes during spring and summer in Balsfjord, northern Norway. Polar Biol 10:113-124

MacKenzie BR, Leggett WC (1993) Wind-based models for estimating the dissipation rates of turbulent energy in aquatic environments: empirical comparisons. Mar Ecol Prog Ser 94:207-216

Margalef R (1978) Life-forms of phytoplankton as survival alternatives in an unstable environment. Oceanol Acta 1: 493-509

Margalef R, Estrada M, Blasco D (1979) Functional morphology of organisms involved in red tides, as adapted to decaying turbulence. In: Taylor DL, Seliger HH (eds) Toxic dinoflagellate blooms. Elsevier, Amsterdam, p 89-94

McCave IN (1984) Size spectra and aggregation of suspended particles in the deep ocean. Deep-Sea Res 31:329-352

Nejstgaard JC, Gismervik I, Solberg PT (1997) Feeding and reproduction by Calanus fnimarchicus, and microzooplankton grazing during mesocosm blooms of diatoms and the coccolithophore Emiliania huxleyi. Mar Ecol Prog Ser 147:197-217

Nielsen TG, Kiørboe T (1991) Effects of a storm event on the structure of the pelagic food web with special emphasis on planktonic ciliates. J Plankton Res 13:35-51

Oakey NS, Elliott JA (1980) Dissipation in the mixed layer near Emerald Basin. In: Nihoul JCJ (ed) Marine turbulence. Elsevier, Amsterdam, p 123-133

Officer CB, Ryther JH (1980) The possible importance of silicon in marine eutrophication. Mar Ecol Prog Ser 3:83-91

Parsons TR, Maita Y, Lalli CM (1984) A manual of chemical and biological methods for seawater analysis. Pergamon Press, Oxford

Passow U (2000) Formation of transparent exopolymer particles, TEP, from dissolved precursor material. Mar Ecol Prog Ser 192:1-11

Passow U, Alldredge AL, Logan BE (1994) The role of particulate carbohydrate exudates in the flocculation of diatom blooms. Deep-Sea Res 41:335-357

Peinert R, von Bodungen B, Smetacek VS (1989) Food web structure and loss rate. In: Berger WH, Smetacek VS, Wefer G (eds) Productivity of the ocean: present and past. John Wiley \& Sons, London, p 35-48

Petersen JE, Sanford LP, Kemp WM (1998) Coastal plankton responses to turbulent mixing in experimental ecosystems. Mar Ecol Prog Ser 171:23-41

Ratkova TN, Wassmann P, Verity PG, Andreassen IJ (1999) Abundance and biomass of pico-, nano- and microplankton along a transect on Nordvestbanken, north Norwegian shelf, in 1994. Sarsia 84:213-225

Riebesell U, Reigstad M, Wassmann P, Noji T, Passow U (1995) On the trophic fate of Phaeocystis pouchetii (Hariot). VI. Significance of Phaeocystis-derived mucus for vertical flux. Neth J Sea Res 33:193-203

Rousseau V, Mathot S, Lancelot C (1990) Calculating carbon biomass of Phaeocystis sp. from microscopic observations. Mar Biol 107:305-314 
Ruiz J (1996) The role of turbulence in the sedimentation loss of pelagic aggregates from the mixed layer. J Mar Res 54: 385-406

Ryther JH, Officer CB (1981) Impact of nutrient enrichment on water uses. In: Crowin NA (ed) Estuaries and nutrients. Humana Press, Totowa, NJ, p 247-261

Smayda TJ (1978) From phytoplankters to biovolume. In: Sournia A (ed) Phytoplankton manual. UNESCO Publications, Paris, p 273-279

Smetacek V, von Bodungen B, Knoppers B, Peinert R, Pollehne F, Stegmann P, Zeitzschel B (1984) Seasonal stages characterizing the annual cycle of an inshore pelagic system. Rapp PV Reun Cons Int Explor Mer 183: $126-135$

Sommer U (1996) Marine food webs under eutrophic conditions: desirable and undesirable forms of nutrient richness. Dtsch Hydrogr Z (Suppl) 6:167-176

Sournia A (1978) Phytoplankton manual. UNESCO, Paris

Steemann Nielsen E (1952) The use of radioactive $\left({ }^{14} \mathrm{C}\right)$ for measuring organic production in the sea. J Cons Int Explor Mer 18:117-140

Stiansen JE, Sundby S (2001) Improved methods for generating and estimating turbulence in tanks suitable for fish larvae experiments. Sci Mar (in press)

Strathmann RR (1967) Estimating the organic carbon content

Editorial responsibility: Otto Kinne (Editor),

Oldendorf/Luhe, Germany of phytoplankton from cell volume or plasma volume. Limnol Oceanogr 12:411-418

Tiselius P, Kuylenstierna M (1996) Growth and decline of a diatom spring bloom: phytoplankton species composition, formation of marine snow and the role of heterotrophic dinoflagellates. J Plankton Res 18:133-155

Utermöhl H (1931) Neue Wege in der quantitativen Erfassung des Planktons (mit besonderer Berücksichtigung des Ultraplanktons). Verh Int Ver Theor Angew Limnol 5: 567-596

Verity PG, Villareal TA, Smayda TJ (1988) Ecological investigations of blooms of colonial Phaeocystis pouchetii. II. The role of the life-cycle phenomena in bloom termination. J Plankton Res 10:749-766

Wassmann P (1994) Significance of sedimentaion for the termination of Phaeocystis blooms. J Mar Syst 5:81-100

Wassmann P, Vernet M, Mitchell BG, Rey F (1990) Mass sedimentation of Phaeocystis pouchetii in the Barents Sea. Mar Ecol Prog Ser 66:183-195

Wassmann P, Egge JK, Reigstad M, Aksnes DL (1996) Influence of dissolved silicate on vertical flux of particulate biogenic matter. Mar Pollut Bull 33:1-6

Welschmeyer NA (1994) Fluorometric analysis of chlorophyll $a$ in the presence of chlorophyll $b$ and phaeopigments. Limnol Oceanogr 39:1985-1992

Submitted: April 10, 2000; Accepted: November 23, 2000 Proofs received from author(s): July 8, 2001 